\title{
The Effect of Mathematical Disposition on Mathematical Power Formation: Review of Dispositional Mental Functions
}

\author{
Imam Kusmaryono \\ Corresponding author, Sultan Agung Islamic University, Semarang, Indonesia, \\ kusmaryono@unissula.ac.id
}

\section{Hardi Suyitno}

Prof., Semarang State University, Semarang, Indonesia, hhardisunnes@yahoo.com

\section{Dwijanto Dwijanto}

Dr., Semarang State University, Semarang, Indonesia,dwijanto5@gmail.com

\author{
Nurkaromah Dwidayati \\ Dr., Semarang State University, Semarang, Indonesia, noengkd_unnes@yahoo.co.id
}

This study applied mixed methods with concurrent triangulation design that combines quantitative and qualitative research method in a balanced manner and convergence. Population in this study was as 188 students of 8 th grade in a state junior high school in Semarang City, Indonesia. By using purposive sampling technique, 60 students were selected as the research subjects. The study aimed to observe the effect of mathematical disposition on students' mathematical power ability, and to describe how dispositional mental functions work when mathematical disposition is developed. Data was collected through written test (essay), questionnaires, observation and interview. Data of research result was then analyzed quantitatively (with analysis of variance) and qualitatively (analysis of interactive model). On the final stage, meta-analysis on the data was conducted. Based on the analysis of quantitative and qualitative data, it could be found that: (1) There was an effect of mathematical disposition (X) on mathematical power ability $(\mathrm{Y})$ by regression equation model $\mathrm{Y}=37.106+0.567 \mathrm{X}$ which was linear on significance level $=0.05$. (2) The teachers should optimize the dispositional mental functions of the students by selecting a learning model that could develop the cognitive, affective, and conative competencies together.

Keywords: effect, mathematical disposition, dispositional mental functions, mathematical power, teaching,

Citation: Kusmaryono, I., Suyitno, H., Dwijanto, D., \& Dwidayati, N. (2019). The Effect of Mathematical Disposition on Mathematical Power Formation: Review of Dispositional Mental Functions. International Journal of Instruction, 343-356. https://doi.org/10.29333/iji.2019.12123a 


\section{INTRODUCTION}

A survey from international institution Trend in International Mathematics and Science Study (TIMSS) and Program for International Student Assessment (PISA) in last 10 years indicated some conspious facts about mathematics education in Indonesia.The achievement index on mathematics in junior high schools in Indonesia is still lower than other developing countries in Asia Pacific (Kemendikbud, 2016). The lower achievement of students learning achievement on mathematics in Indonesia has become a serious concern in education field.

Mathematics learning is not just to help students but to gain skills and strategy in problem solving. However, involving mental attitude and development of mathematical disposition is an effective way to observe the situation (Watson, 2015). From the perspective of pedagogy, considered as the important aspects in mathematics learning are to influence students' mathematical disposition and help them to develop their selfperception as members of mathematics learners community (Boaler, in Sansome, 2016). In mathematical power, students are required to be able to use ability of communication, reasoning, connecting mathematical ideas to solve problems, and transforming positive attitude toward mathematics (positive mathematical disposition) (Kusmaryono, Suyitno, \& Dwidayati, 2018). Considering the importance of mathematical disposition factors toward mathematics learning achievement, hence this problem should be studied.

Mathematical disposition has a long-term effect in terms of students convincement toward mathematics (NCTM, 2014). Mathematics still become a hated and not enjoyable subject in schools. Even many junior high school students are failed to enroll in mathematics and science class in senior high school. It is not because they don't have the ability, but their negative disposition or negative perception toward mathematics. Teachers are challenged to transform their negative mathematical disposition into positive (productive) mathematical disposition, so that they trust in mathematical power and function to solve problems and for their future career progress (Cai, Robison, Moyer, \& Wang, 2012).

Disposition is a trust or tendency that encourages a person to behave (response and action) (Biber, Tuna, \& Incikabi, 2013). What a person thinks will be actualized in actions. The actions will be well and taken directedly if the mental function is in a good and controlled condition. Then, psychologically the mathematical disposition would closely relate to the mental function.

Mathematical disposition is defined as one's belief or behavior about mathematics supporting a tendency to observe mathematics as something logical, useful and valuable (Feldhaus, 2014; Rahayu \& Kartono, 2014). Mathematical disposition relates to a person's mental function. In this research, mathematical disposition refers to the aspects of the 3 dispositional mental functions developed by James Beyers including (1) Cognitive dispositional mental function, (2) Affective dispositional mental function, and (3) Connative dispositional mental function (Beyers, 2011).

The standard of contents of Indonesia's curriculum 2013 clearly mentions that the competence of mathematics learning is that students have a trust in mathematical power 
and function transformed through learning experiences (BSNP, 2013). Summed up from some literatures, mathematical power is defined as an ability to use mathematical knowledge to solve non routine problems; through reasoning, communication and connectionto improve mathematical confidence and dispositions (Pilten, 2010; Şahin \& Baki, 2010). Mathematical power is an important basic thing for each person who is going to learn mathematics. This statement is because mathematical power influences the ways of process and learning result of a person to gain knowledge, skill and stance that will be reflected in daily life (Kusmaryono, 2014). Mathematical power plays a role to spur the interdisciplinary success of students appreciation and learning complexities (Kastberg \& D'Ambrosio, 2015). A research result done by experts mentioned that students'mathematical power in junior high schools was still low. It is because the negative disposition on mathematics has influenced their performance in doing mathematics tasks (Mueller \& Hindin, 2011; Sumarmo, Hidayat, Zukarnaen, Hamidah, \& Sariningsih, 2012).

In this study, teachers applied group investigation approach within the mathematics learning model. Investigation approach was chosen to encourage students' positive disposition on mathematics and skills to conduct mathematical observation and also to promote mathematics as a way of thinking (Richardson, Stein Schwartz, \& Reynolds, 2010; Ulrich \& Wilkins, 2017). The purposes of the study were (1) to determine the effect of mathematical disposition on mathematical power abilities, and (2) to describe how dispositional mental functions work when the mathematical disposition is developed. Hopefully, this study would bring benefits for parents and teachers. Parents could encourage the development of students' positive mathematical disposition. Teachers could activate students' dispositional mental functions (cognitive, affective, and connative) optimally in mathematics learning.

\section{METHOD}

\section{Research Design}

The research was conducted on April - June 2017. It took place in Junior High Schools managed by Semarang City Governement in Indonesia.It employed mixed methods with concurrent triangulation i.e. combining qualitative and quantitative methods in a balanced manner and convergence (Creswell, 2014).

\section{Participants}

The subjects participated in this study were 188 students of $8^{\text {th }}$ grade. Two mathematics teachers also joined in participation. One of the two took a role as a teacher in mathematics class, while the other observed how mathematics learning was conducted.

\section{Procedure}

At the beginning of the research, the questionnaire of mathematical disposition was delivered to 188 subjects (population). The result of the questionnaire was then analyzed meticulously and thoroughly. By purposive sampling technique, 30 subjects with positive mathematical disposition were selected as Group 1, and 30 subjects with negative mathematical disposition were selected as Group 2. Both groups had similar 
treatment in the mathematics learning for 6 meetings in classroom. An observation was conducted during the learning process and the result was recorded. At the end of the learning, the subjects from both groups had a work on a mathematical power skill test. To collect deeper information about mathematical disposition, 2 subjects (students) were selected as representatives of each group to be interviewed.

\section{Instruments}

The instruments used to collect data were test (written test) and non-test (questionnaire, observation, and interview). The questionnaires were constructed based on dispositional mental function indicators. There were 20 questions in each questionnaire. The observation sheets were used to record information of how the mathematics lesson was conducted. The written test had 3 items of mathematical power: reasoning, communication, and connecting. The test was used to collect data about mathematical power ability. The interview contained questions arranged carefully to collect deeper information about students' mathematical disposition. All these instruments had gained recommendation by a validation team filled by experts of each field, and met all the requirements of validity and reliability tests as data collection instruments. Instrument validity test with product moment correlation showed that all instrument items value $r>$ 0.444 and instrument reliability test with Cronbach's Alpha value $r=0.797>0.444$ with significance level 0.05 .

\section{Data Collection and Analysis}

Quantitative and qualitative data were collected congruently (at the same time). The quantitative data were analyzed by regression test: analysis of variants (anova). The qualitative data were analyzed with interactive model: data collection, data reduction, data presentation, and drawing conclusion. Data validity test used triangulation method (Creswell, 2014). After that, all the data collected from both methods were compared by meta-analysis. The stages of meta-analysis: data was grouped, defined, and determined the connection among each data, so the final conclusion could be drawn if both data affirmed, weaken, or were against each other (Creswell, 2014).

\section{FINDINGS}

\section{The influence of mathematical dispositions on mathematical power ability}

The questionnaires of mathematical disposition were completed by the respondents by putting a check mark $(\sqrt{ })$ in the columns of scale $1,2,3,4$, or 5 based on the questions. The recap of mathematical disposition questionnaire result score is presented in Table 1.

Table 1

Mathematical disposition scores of each group

\begin{tabular}{llllll}
\hline & $\mathrm{N}$ & Minimum & Maximum & Mean & Std. Dev \\
\hline Group 1 & 30 & 65 & 87 & 73.86 & 6.117 \\
Group 2 & 30 & 45 & 65 & 58.30 & 4.580 \\
\hline
\end{tabular}

Based on Table 1, it could be known that mathematical disposition scores for students in Group 1: 65 minimum score, 87 maximum score, and 73.86 average score with 6.117 of 
standard deviation. In Group 2, the students got mathematical disposition scores as: 45 minimum score, 65 maximum score, and 58.30 average score. There was a significant difference in average scores of mathematical disposition between both groups. Students in Group 1 had fairly high category of mathematical disposition (positive mathematical disposition) while members of Group 2 had a low category of mathematical disposition (negative mathematical disposition). The statistic of mathematical disposition indicator achievement between both groups is presented in Table 2 .

Table 2

The statistic of mathematical disposition indicator achievement between groups

\begin{tabular}{|c|c|c|c|c|c|c|}
\hline \multirow{2}{*}{$\begin{array}{l}\text { Modes of Mental } \\
\text { Functioning }\end{array}$} & \multirow{2}{*}{$\begin{array}{l}\text { Subcategory of } \\
\text { dispositional } \\
\text { function }\end{array}$} & \multicolumn{5}{|c|}{ Mathematical Disposition Score } \\
\hline & & $\begin{array}{l}\text { Group } \\
1\end{array}$ & $\begin{array}{l}\text { Group } \\
2\end{array}$ & $\begin{array}{l}\text { Means } \\
\text { G1 }\end{array}$ & $\begin{array}{l}\text { Means } \\
\text { G2 }\end{array}$ & $\begin{array}{l}\text { Means } \\
\text { Different }\end{array}$ \\
\hline \multirow{2}{*}{$\begin{array}{l}\text { Dispositional } \\
\text { cognitive } \\
\text { function }\end{array}$} & Connections & 206 & 178 & 3.43 & 2.97 & 0.46 \\
\hline & Argumentation & 212 & 173 & 3.53 & 2.88 & 0.65 \\
\hline \multirow[t]{7}{*}{$\begin{array}{l}\text { Dispositional } \\
\text { affective function }\end{array}$} & $\begin{array}{l}\text { Nature of } \\
\text { Mathematics }\end{array}$ & 217 & 184 & 3.62 & 3.06 & 0.56 \\
\hline & Usefulness & 216 & 173 & 3.60 & 2.88 & 0.72 \\
\hline & Worth Whileness & 223 & 199 & 3.72 & 3.32 & 0.40 \\
\hline & Sensibleness & 203 & 193 & 3.38 & 3.22 & 0.16 \\
\hline & Self-Concept & 213 & 184 & 3.55 & 3.07 & 0.48 \\
\hline & Attitude & 204 & 170 & 3.40 & 2.83 & 0.43 \\
\hline & Math Anxiety & 210 & 200 & 3.50 & 3.33 & 0.23 \\
\hline $\begin{array}{l}\text { Dispositional } \\
\text { conative function }\end{array}$ & Effort/Persistence & 221 & 201 & 3.68 & 3.35 & 0.33 \\
\hline Total & & 2125 & 1855 & 3.54 & 3.09 & 0.45 \\
\hline
\end{tabular}

Notes: Group1 (G1): Students with positive mathematical disposition.

Group 2 (G2): Students with negative mathematical disposition.

Considering Table 2, the achievement of mathematical disposition indicators by students in Group 1 obtained 2125 total score; while in Group 2 resulted 1855 total score. Each indicator had $10-43$ difference in mathematical disposition scores. Group 1 had 3.54 average score, Group 2 had 3.09 average score, and the difference of the average was 0.45 .

Data of mathematical power ability test result was collected through test (pencils and paper test) method. The test was conducted at the end of learning in sixth meeting. The purpose of this test is to get data about mathematical power cognitive abilities as learning outcomes. Statistic description of students' mathematical power test result between both groups is presented in Table 3 .

Table 3

Description of mathematical power score between groups

\begin{tabular}{lccccc}
\hline Group & $\mathrm{N}$ & Minimum & Maximum & Mean & Std. Dev \\
\hline Group 1 & 30 & 48 & 98 & 75.60 & 10,769 \\
Group 2 & 30 & 40 & 85 & 67.68 & 10.979 \\
\hline
\end{tabular}


Table 3 indicates that mathematical power ability test by students in Group 1 resulted 48.0 minimum score, 98.0 maximum score and 75.60 mean score with 10.769 standard deviation. Group 2 had 40 minimum score, 85 maximum score, and 67.68 average score with 10.979 of standard deviation. The difference in average score achievement of mathematical power ability between the two groups was 7.92 points. To observe if there was an effect of mathematical disposition on mathematical power, the data was analyzed using a program named Statistical Package for Social Sciences (SPSS) version 20.0. The result of data analysis is presented on Table 4 .

Table 4

Output coefficients

\begin{tabular}{|c|c|c|c|c|c|}
\hline \multirow[t]{2}{*}{ Model } & \multicolumn{2}{|c|}{$\begin{array}{l}\text { Unstandardized } \\
\text { Coefficients }\end{array}$} & $\begin{array}{l}\text { Standardized } \\
\text { Coefficients }\end{array}$ & \multirow[t]{2}{*}{$\mathrm{t}$} & \multirow[t]{2}{*}{ Sig. } \\
\hline & $\mathrm{B}$ & Std. Error & Beta & & \\
\hline (Constant) & 37.106 & 7.968 & & 4.657 & .000 \\
\hline${ }^{1}$ Mathematical Disposition (X) & .567 & .123 & .516 & 4.593 & .000 \\
\hline
\end{tabular}

The output coefficients on Table 4 showed that value of constant (a) $=37.106$ and coefficient of $\mathrm{X}(\mathrm{b})=0.567$, so that the linear regression equation $\mathrm{Y}=37.106+0.567 \mathrm{X}$ is obtained as the estimation equation. To accept or dismiss characteristics of linear equation is presented in Table 5.

Table 5

Regression test (analysis of variance)

\begin{tabular}{|c|c|c|c|c|c|}
\hline Model & Sum of Squares & df & Mean Square & $\mathrm{F}$ & Sig. \\
\hline 1 Regression & 1675.541 & 1 & 1675.541 & 21.092 & $0.000^{b}$ \\
\hline Residual & 4607.443 & 58 & 79.439 & & \\
\hline Total & 6282.983 & 59 & & & \\
\hline
\end{tabular}

a. Dependent Variable: Math Power Y

b. Predictors: (Constant), Disposition $\mathrm{X}$

Table 5 presented the result of data analysis through regression test, showing that significance $(\mathrm{Sig})$ value $0.000^{\mathrm{b}}$ is less than 0.05 , so the null hypothesis $\left(\mathrm{H}_{0}\right)$ was dismissed and alternative hypothesis $\left(\mathrm{H}_{1}\right)$ was accepted. This condition was interpreted that variable $\mathrm{X}$ had a linear connection to variable $\mathrm{Y}$ with a fairly significant regression coefficient. Amount of effect of variable $\mathrm{X}$ on $\mathrm{Y}$, by calculation of $\mathrm{R}$ square value, showed that variations happened in mathematical power ability $(\mathrm{Y})$ could be explained by mathematical disposition variable $(X)$ by $26.7 \%$. In other words, variable $X$ influenced variable $\mathrm{Y}$ by $26.7 \%$ significantly with regression model $\mathrm{Y}=37.106+$ $0.567 \mathrm{X}$ by $73.3 \%$ influenced by other variables.

\section{Performance of cognitive, affective and connative dispositional mental functions}

To complete qualitative data for this research, the author selected 2 students (male and female) from Group 1 and 2 students (male and female) from Group 2 as the interviewees. The interview was managed to collect deeper and more complete 
information about their mathematical disposition. The result of the interview was recorded, and then reduced to be presented in an interview script as follows.

Table 6

Script of interview: Cognitive dispositional mental function

\begin{tabular}{|c|c|c|c|}
\hline $\begin{array}{l}\text { Modes of Mental } \\
\text { Functioning }\end{array}$ & Interview Questions & $\begin{array}{l}\text { Response by } \\
\text { Subjects from } \\
\text { Group } 1\end{array}$ & $\begin{array}{l}\text { Response by } \\
\text { Subjects from } \\
\text { Group } 2\end{array}$ \\
\hline \multicolumn{4}{|c|}{ 1. Dispositional Cognitive Function } \\
\hline 1.1 Connections & $\begin{array}{l}\text { Did you always } \\
\text { connect among } \\
\text { mathematical ideas in } \\
\text { every problem solving? }\end{array}$ & $\begin{array}{l}\text { Yes, I did. I } \\
\text { connected ideas to } \\
\text { solve problems. }\end{array}$ & $\begin{array}{l}\text { Mathematics drove } \\
\text { me crazy for it has } \\
\text { many complicated } \\
\text { formulas. }\end{array}$ \\
\hline Argumentation & $\begin{array}{l}\text { Did you always } \\
\text { provide reasons for } \\
\text { every answer? }\end{array}$ & $\begin{array}{l}\text { I was always } \\
\text { required to provide } \\
\text { rasional reasons. }\end{array}$ & $\begin{array}{l}\text { I often forgot and } \\
\text { knew nothing, I } \\
\text { could not think. }\end{array}$ \\
\hline
\end{tabular}

Table 6 cognitive dispositional mental function is a tendency to be actively involved in certain cognitive mental processes (Beyers, 2011), for example: the tendency to link ideas or mathematical concepts to solve problems, propensities to reason and give reasons for action- math task. Interview result shows that group 1 subject is very ready in cognitive mental process. While the subject of group 2 appears that the subject does not have the tendency to make connections and member reasons about the thought process. 
Table 7

Script of interview: Affective dispositional mental function

\begin{tabular}{|c|c|c|c|c|}
\hline \multicolumn{2}{|c|}{$\begin{array}{l}\text { Modes of Mental } \\
\text { Functioning }\end{array}$} & \multirow[t]{2}{*}{ Interview Questions } & \multirow[t]{2}{*}{$\begin{array}{l}\text { Response by Subjects } \\
\text { from Group } 1\end{array}$} & \multirow[t]{2}{*}{$\begin{array}{l}\text { Response by Subjects } \\
\text { from Group } 2\end{array}$} \\
\hline \multicolumn{2}{|c|}{ 1. Dispositional Affective Function } & & & \\
\hline 2.1 & $\begin{array}{l}\text { Nature of } \\
\text { Mathematics }\end{array}$ & $\begin{array}{l}\text { Are you sure that } \\
\text { mathematical concepts } \\
\text { are connected each } \\
\text { other? }\end{array}$ & $\begin{array}{l}\text { I'm sure, } \\
\text { mathematics nature is } \\
\text { that concepts must be } \\
\text { connected each other. }\end{array}$ & $\begin{array}{l}\text { I'm not sure, } \\
\text { mathematical } \\
\text { concepts are } \\
\text { separated. }\end{array}$ \\
\hline 2.2 & Usefulness & $\begin{array}{l}\text { How much benefit } \\
\text { mathematics gives for } \\
\text { your daily activities? }\end{array}$ & $\begin{array}{l}\text { I believe that } \\
\text { mathematics is useful } \\
\text { for daily life and } \\
\text { future career } \\
\text { selection. }\end{array}$ & $\begin{array}{l}\text { Mathematics does a } \\
\text { little favour in my life. }\end{array}$ \\
\hline 2.3 & $\begin{array}{l}\text { Worth } \\
\text { Whileness }\end{array}$ & $\begin{array}{l}\text { Are your mathematicals } \\
\text { tasks worthy? }\end{array}$ & $\begin{array}{l}\text { Yes, they are. I } \\
\text { believe and can do it. } \\
\text { I am also proud that } \\
\text { the tasks are worthy. }\end{array}$ & $\begin{array}{l}\text { I am not sure that my } \\
\text { tasks are worthy, } \\
\text { because teachers did } \\
\text { not motivate to learn. }\end{array}$ \\
\hline 2.4 & Sensibleness & $\begin{array}{l}\text { Could you interpret } \\
\text { abstract ideas? }\end{array}$ & $\begin{array}{l}\text { I could understand } \\
\text { abstract ideas, but } \\
\text { still lack of studying, } \\
\text { I think. }\end{array}$ & $\begin{array}{l}\text { I could not. } \\
\text { Everything seemed to } \\
\text { be hard to calculate. }\end{array}$ \\
\hline 2.5 & Self-Concept & $\begin{array}{l}\text { Did you always re-check } \\
\text { your mathematics } \\
\text { works? }\end{array}$ & $\begin{array}{l}\text { Yes, I did a re-check } \\
\text { on my works that } \\
\text { seemed to be } \\
\text { incorrect. }\end{array}$ & $\begin{array}{l}\text { I was careless and did } \\
\text { not realize that my } \\
\text { works were incorrect. }\end{array}$ \\
\hline 2.6 & Attitude & $\begin{array}{l}\text { Do you always like } \\
\text { mathematics? }\end{array}$ & $\begin{array}{l}\text { Yes, I do, } \\
\text { mathematics is } \\
\text { challenging. }\end{array}$ & $\begin{array}{l}\text { Mathematics is a } \\
\text { nightmare. The } \\
\text { teacher gave many } \\
\text { tasks. }\end{array}$ \\
\hline 2.8 & Math Anxiety & $\begin{array}{l}\text { Are you worried if you } \\
\text { did not succeed to } \\
\text { complete the task? }\end{array}$ & $\begin{array}{l}\text { I am always worried } \\
\text { and expect that the } \\
\text { result will not be } \\
\text { disapointing. }\end{array}$ & $\begin{array}{l}\text { I am not worried if I } \\
\text { get low achievement } \\
\text { on mathematics. }\end{array}$ \\
\hline
\end{tabular}

Affective dispositional mental function is defined as a tendency to like or dislike; a feeling of confidence or uncertainty and responses to certain mathematical ideas (Beyers, 2011). The domain reaction to affective mental function includes six subcategories: nature of mathematics, usefulness, worth whileness, sensibleness, selfconcept mathematics, attitude, and math anxiety. Overall the subject of group 1 has a positive attitude towards their mental activity. The subject (Group 1) has a good SelfConcept to be aware and able to manage or control the thinking way that led to mathematics learning success. Anxiety over taking the subject (group 1) couldnot be considered as a weakness, but as a strong motivation to gain the best learning result. On the other hand, subjects in Group 2 of their anxiety often turned into a negative presumption toward mathematics tasks (Geist, 2010). The subjects of group 2 felt that 
he did not need to be anxious to have mathematics tasks, because the mathematics score achievement would not influence their negative stance toward mathematics.

Table 8

Script of interview: Connative dispositional mental function

\begin{tabular}{|c|c|c|c|}
\hline $\begin{array}{l}\text { Modes of Mental } \\
\text { Functioning }\end{array}$ & Interview Questions & $\begin{array}{l}\text { Response } \\
\text { Subjects } \\
\text { Group 1 }\end{array}$ & $\begin{array}{l}\text { Response by Subjects } \\
\text { from Group } 2\end{array}$ \\
\hline \multicolumn{4}{|c|}{ 3. Dispositional Connative Function } \\
\hline $\begin{array}{ll}3.1 & \text { Effort/ } \\
& \text { Persistence }\end{array}$ & $\begin{array}{l}\text { Did you give your } \\
\text { best effort to get } \\
\text { perfect result? }\end{array}$ & $\begin{array}{l}\text { I prepared myself } \\
\text { with studying hard } \\
\text { in order to succeed. }\end{array}$ & $\begin{array}{l}\text { I'm not expert in } \\
\text { mathematics, No. } \\
\text { need to deal with } \\
\text { mathematics. }\end{array}$ \\
\hline
\end{tabular}

Connative dispositional mental function is one's tendency to be passionate, effort, and diligently practicing in the face of difficult mathematical tasks and view the difficult task as a challenging mathematical activity. The results of this interview indicate that the response from Group 1 had a great deal of effort and did not give up on mathematical tasks. But in group 2, the subject seems to be uninspired and sees no need for hard work, as it will not be a mathematician.

\section{DISCUSSION}

\section{Influence of mathematical dispositions on mathematical power}

Empirically both groups had a very different mathematical disposition. Data description showed that students of Group 1 with positive dispositional mathematics had high mathematical power (learning achievement), while the members of Group 2 with negative mathematical disposition had low mathematical power (learning achievement) (see Table 1 and 3). Thus, it was assumed that there was a linear relation between mathematical disposition and mathematical power. Increasing and decreasing of mathematical power $(\mathrm{Y})$ variable score was influenced by the score of mathematical disposition variable. Considering regression equation $\mathrm{Y}=37.106+0.567 \mathrm{X}$ (see Table 4 ), said that each score increasing as one unit of mathematical disposition (X) variable so it would cause an increasing in the score of mathematical power variable (Y) as 0.567 points.

\section{Factors of Dispositional Mental Function}

Statistics of mathematical disposition indicator achievement by both Group 1 and Group 2 on dispositional mental function mode (Table 2) showed that there was a significant difference of scores. Furthermore, the indicators of dispositional mental functions that had a large difference in scores between both groups were connections, attitude, selfconcept, and effort/persistence. All of these will be discussed in this part by involving interview result on Table 6,7 , and 8 .

Attitude, like and dislike on mathematics are very easy to recognize from someone's attitude of mathematical disposition. Group 1 students with positive mathematical disposition seemed to like mathematics with high enthusiasm in class. They actively had 
a discussion with friends, provided comments to each other works. The average score of mathematical power by Group 1 students was categorized as high category. This high score achievement was inevitably because of their skills of connecting, arguing, diligence, toughness and effort/persistence to solve problems when it was complicated. On the other hand, they considered mathematics as something challenging to solve. The students had fairly good concept comprehension and mathematical representation, so they succeeded to solve mathematical problems that were abstract (Supandi, Waluya, Suyitno, \& Dewi, 2018). At the reflection stage, the students in Group 1 had a high level of awareness to re-check their works. They hada good self-concept, to be aware and able to manage the way of thinking that led to the mathematics learning success. This selfconcept is called as meta-cognition, that is, a process of awareness to manage and control how to think so that it could assist the success of intellectual tasks (Lukum, Laliyo, \& Sukamto, 2015; Panjaitan, 2015; Qohar \& Sumarmo, 2013).

Students of Group 2 with negative mathematical disposition, based on attitude, seemed to dislike mathematics when they were lack of motivation to learn and complete the tasks, and reluctant to ask if they met obstacles in tasks given. Self-concept, as students' awareness to do reflection on their works was very low. They did not understand what they had to work because they had lack skill of connecting mathematical ideas (mathematical connections). When interviewed, they failed in the task that required high abstraction power. They were not able to give reasons on their answers in their works. Most of students were not too diligent and lack of efforts (effort/persistence). They were not confident with their ability. It should influence their level of persistence. Diligence and curiosity were components of mathematical disposition which have a strong effect in problem solving (Rahayu \& Kartono, 2014). Students with negative mathematical disposition commonly showed a low confidence and lack of motivation to learn mathematics (An, Tillman, Boren, \& Wang, 2014; Cai et al., 2012). What most worrying is that when they have negative mathematical disposition, they consider that mathematics is not useful for their lives, and it would influence their career in the future.

The explanation above shows that dispositional mental function i.e. connections, attitude, self-concept, and effort/persistence work together in students. Thus, dispositional mental functions of cognitive, affective and connative worked together and related each other. This statement is confirmed by what was stated by James Beyers (Beyers, 2011), that three dispositional mental functions (cognitive, affective, and connative) can work together when mathematical disposition is developed.

\section{Teacher Attitude and Behaviour Factors}

The result of interview on students (see Table $6 \mathrm{a}, 6 \mathrm{~b}$, and $6 \mathrm{c}$ ) indicated that negative mathematical disposition was also formed of teacher performance, attitude and behaviour in class (Pardimin \& Huda, 2018). The behaviour that students disliked was that teacher did not include and provide attention to those of having low cognitive ability, and lack of motivation from teacher to students. Some students pychologically experienced high stress having tasks on mathematics because of non-cooperative behavior from teachers (Geist, 2010; Odebode, 2018). So, mathematics was not the cause of anxiety for students, but it was non-cooperative behavior and attitudes from 
teachers that led to an anxiety and a negative disposition for students toward mathematics learning (Bingolbali, Akkoç, Ozmantar, \& Demir, 2011; Geist, 2010).

It was a hard work to transform students' mathematics disposition, from negative to positive. According to Adam Feldhaus, mathematics disposition was already formed in their beginning of mathematics career, so it was hard to transform on the other day (Feldhaus, 2014). However, after positive attitude and trust in mathematics was developed, students would have satisfying stability and intensity level (Rahayu \& Kartono, 2014). By group investigation learning, the students had a meaningful learning experience. Adam Feldhaus further explained that students get a meaningful experience in learning and a person's experience could form a mathematical disposition (Feldhaus, 2014). Furthermore, teachers' social skill and communication skill to effectively communicate with students are very important to be applied in mathematics learning to produce better positive attitude and performance by students.

\section{Meta-Analysis}

The empirical data showed that students with negative mathematical disposition had a low mathematical power. Students with positive mathematical disposition had a high mathematical power. It means that there was an influence between mathematical disposition and mathematical power ability. Statistics of regression test showed that there was a significant influence of mathematical disposition on mathematical power ability.

The result of qualitative research showed an internal consistency among the three dispositional mental functions. The three dispositional mental functions (cognitive, affective, and connative) worked together when mathematical disposition was developed.

Mathematical power was formed to develop productive mathematical disposition and confidence, while the productive mathematical disposition had a tendency to improve mathematical power ability. So there was a reciprocal connection between mathematical power and disposition. It is clear in stages of meta-analysis of this data, that mathematical power ability (quantitative) and mathematical disposition (qualitative) were supporting each other and confirmed the findings.

\section{CONCLUSION AND RECOMMENDATIONS}

Based on qualitative and quantitative data analysis, it can be concluded that: (1) there is an effect of mathematical disposition (X) on mathematical power (Y) by regression equation model $\mathrm{Y}=37.106+0.567 \mathrm{X}$ which is linear on significance level $\alpha=0.05$. By the previous regression equation, it could be explained that one unit increasing on mathematical disposition variable score $(\mathrm{X})$ led to an increasing on mathematical power variable score (Y) as 0.567 point. (2) Dispositional mental functions of cognitive, affective and connative worked together and related each other. These three dispositional mental functions (cognitive, affective, and connative) consistently contributed (worked and functioned) together while the mathematical disposition was being developed. Behavior, attitudes and awareness of teachers about students' 
mathematical dispositions are important factors that influence students' mathematical dispositions and to assess the effectiveness and quality of mathematics teachers. Furthermore, the author suggested teachers to: (a) be more aware and understand about mathematics knowledge, mathematical disposition, and self-perception of the students in order to fulfil their needs as learners, (b) optimize the students' dispositional mental function in a learning by selecting a learning model that was proper to develop the competences of cognitive, affective and conative altogether, and (c) the teachers should have positive mathematical disposition and equip themselves with social skill, communication skill, and professional performace in order to motivate students and grow their positive disposition toward mathematics learning.

\section{REFERENCES}

An, S. A., Tillman, D. A., Boren, R., \& Wang, J. (2014). Fostering Elementary Students' Mathematics Disposition through Music-Mathematics Integrated Lessons. International Journal for Mathematics Teaching \& Learning, 4(2), 19.

Beyers, J. (2011). Development and Evaluation of an Instrument to Assess Prospective teachers ' dispositions with respect to mathematics. International Journal of Business and Social Science, 2(16), 20-33.

Biber, A. C., Tuna, A., \& Incikabi, L. (2013). An Investigation of Critical Thinking Dispositions of Mathematics Teacher Candidates. Educational Research, 4(2), 21415161. Retrieved from http://www.interesjournals.org/ER

Bingolbali, E., Akkoç, H., Ozmantar, M. F., \& Demir, S. (2011). Pre-Service and InService Teachers' Views of the Sources of Students' Mathematical Difficulties. International Electronic Journal of Mathematics Education, 6(1), 40-59. Retrieved from 79952253159\&origin=resultslist\&sort

http://www.scopus.com/record/display.url?eid=2-s2.0-

BSNP. Salinan Permendikbud R.I. Nomor 64 Tahun 2013.Tentang Standar Isi Pendidikan Dasar dan Menengah., Pub. L. No. 1-114, 1 (2013). Kemendikbud RI. Retrieved from https://luk.staff.ugm.ac.id/atur/bsnp/Permendikbud642013StandarIsi.pdf

Cai, J., Robison, V., Moyer, J., \& Wang, N. (2012). Mathematical Dispositions and Student Learning: A Metaphorical Analysis. AERA Online Paper Repository, 1-9. Retrieved from http://www.aera.net/Publications/Online-Paper-Repository

Creswell, J. W. (2014). Research Design: Qualitative, Quantitative, and Mixed Methods Approaches. SAGE Publications, Inc. 2455 Teller Road Thousand Oaks, California 91320.

Feldhaus, C. A. (2014). How Pre Service Elementary School Teachers' Mathematical Dispositions are Influenced by School Mathematics. American International Journal of Contemporary Research, 4(6), 91-97. Retrieved from http://www.aijcrnet.com/journals/Vol_4_No_6_June_2014/11.pdf 
Geist, E. (2010). The Anti-Anxiety Curriculum: Combating Math Anxiety in the Classroom. Journal Of Instructional Psychology, 37(1), 24-31. Retrieved from https://eric.ed.gov/?id=EJ952295

Kastberg, S., \& D’Ambrosio, B. (2015). Context Matters in Assessing Students' Mathematical Power. For the Learning of Mathematics, 25(2), 10-15. Retrieved from http://www.jstor.org/stable/40248490

Kemendikbud. (2016). Hasil Surve TIMSS 2015 (Vol. Desember). Indonesia. Retrieved from https://puspendik.kemdikbud.go.id/seminar/upload/Hasil Seminar Puspendik 2016/Rahmawati-Seminar Hasil TIMSS 2015.pdf

Kusmaryono, I. (2014). The Importance of Mathematical Power in Mathematics Learning. International Conference on Mathematics, Science, and Education 2014 (ICMSE 2014), 2014(ICMSE), 35-40.

Kusmaryono, I., Suyitno, H., Dwijanto, D., \& Dwidayati, N. K. (2018). Developing Assessment Instrument as a Mathematical Power Measurement. Journal of Education and Learning, 12(3), 382-391. https://doi.org/10.11591/edulearn.v12i3.7343

Lukum, A., Laliyo, L. A. R., \& Sukamto, K. (2015). Metakognisi Mahasiswa Dalam Pembelajaran Kesetimbangan Kimia. Jurnal Ilmu Pendidikan, 21(1), 9-18.

Mueller, M., \& Hindin, A. (2011). An analysis of the Factors that Influence Preservice Elementary Teachers' Developing Dispositions about Teaching all Children. Issues in Teacher Education, 20(1), 17-34. https://doi.org/10.1080/08878730.2010.489992

NCTM. (2014). NCTM Disposition 2011 | mjcoonkitt. Retrieved December 15, 2017, from https://mjcoonkitt.wordpress.com/2014/06/18/nctm-disposition-2011/

Odebode, A. A. (2018). Influence of Psychosocial Factors on Adherence. International Journal of Instruction, 11(3), 233-243.

Panjaitan, B. (2015). Karakteristik Metakognisi Siswa. Jurnal Ilmu Pendidikan, 21(1), 19-28.

Pardimin, P., \& Huda, M. (2018). Investigating Factors Influencing Mathematics Teaching Performance: An Empirical Study. International Journal of Instruction, 11(3), 391-402.

Pilten, P. (2010). Evaluation of Mathematical Powers of 5th Grade Primary School Students. Procedia - Social and Behavioral Sciences, 2(2), 2975-2979. https://doi.org/10.1016/j.sbspro.2010.03.450

Qohar, A., \& Sumarmo, U. (2013). Improving Mathematical Communication Ability and Self Regulation Learning Of Yunior High Students by Using Reciprocal Teaching. IndoMS.Journal on Mathematics Education, 4(1), 59-74.

Rahayu, R., \& Kartono. (2014). The Effect of Mathematical Disposition toward Problem Solving Ability Based On IDEAL Problem Solver. International Journal of Science and Research (IJSR), 3(10), 2012-2015. 
Richardson, K., Stein Schwartz, C., \& Reynolds, A. (2010). Investigating Quadrilaterals as an Ongoing Task. International Journal for Mathematics Teaching and Learning [Electronic Only], 2010, 1-21.

Şahin, S. M., \& Baki, A. (2010). A new model to assess Mathematical Power. Procedia - Social and Behavioral Sciences, 9, 1368-1372. https://doi.org/10.1016/j.sbspro.2010.12.336

Sansome, E. J. (2016). Building teachers ' pedagogy practices in reasoning, to improve students ' dispositions towards mathematics. Theses. Quesland Universty of Technology. (March, 2016).

Sumarmo, U., Hidayat, W., Zukarnaen, R., Hamidah, \& Sariningsih, R. (2012). Kemampuan dan Disposisi Berpikir Logis, Kritis, dan Kreatif Matematik. Jurnal Pengajaran MIPA, 17, 17-33. https://doi.org/10.18269/jpmipa.v17i1.228

Supandi, S., Waluya, B., Suyitno, H., \& Dewi, K. (2018). Think-Talk-Write Model for improving Students' Abilities in Mathematical Representation. International Journal of Instruction, 11(3), 77-90.

Ulrich, C., \& Wilkins, J. L. M. (2017). Using Written Work to Investigate Stages in Sixth-grade Students' Construction and Coordination of Units. International Journal of STEM Education, 4(1), 23. https://doi.org/10.1186/s40594-017-0085-0

Watson, K. L. (2015). Examining the Effects of College Algebra on Students' Mathematical Dispositions. All Theses and Dissertations, Paper 5601. Brigham Young University: BYU Scholar Archive. Retrieved from https://scholarsarchive.byu.edu/etd/5601 